\title{
Intraguild predation in raptor assemblages: a review
}

\author{
FABRIZIO SERGIO* \& FERNANDO HIRALDO \\ Department of Applied Biology, Estacion Biologica de Doñana, Sevilla, Spain
}

\begin{abstract}
Intraguild predation, the killing of species that use similar resources, has been largely overlooked in raptor investigations. To help fill this gap in knowledge, we conducted a literature review, focusing on studies that tested the behavioural and demographic impact of intraguild predation on individuals, populations, and assemblages of diurnal and nocturnal raptorial species. Overall, data were available for 39 empirical and experimental studies on 63 populations belonging to 11 killer species and 15 victim species. An overview of these studies suggested that intraguild predation was a widespread, size-based phenomenon. Results from multiple studies on the same species at different locations were usually consistent across wide geographical areas. Individual-level demographic impacts included reduced site-occupancy, breeding success and survival. Individuals of the prey species responded to predation pressure through direct spatial avoidance, risk-sensitive habitat selection, short-term behavioural avoidance (e.g. reduced vocal activity and escape to refugia after predator detection) and, possibly, temporal segregation. Population-level effects were common but mainly examined as spatio-temporal correlations between the abundance of killer and victim species. Correlative evidence also suggested that intraguild predation may have the potential to structure whole raptor assemblages. More studies on other species and different geographic areas are needed to increase our understanding of the causes and consequences of this widespread interaction. From a conservation point of view, intraguild predation may limit the success of raptor preservation programmes and could be used as a management tool through its effect on mesopredator release and its potentially positive, indirect effects on game species.
\end{abstract}

Keywords: Birds of prey, competition, interaction, owl, trait-mediated effects.

In traditional food web dynamics, predation acts mainly across and at lower trophic levels while competition is more influential within higher trophic levels (e.g. Schoener 1983, Sih et al. 1985). As a consequence, upper trophic level consumers, such as many raptorial species, have often been depicted as relatively free from predation (Korpimäki \& Norrdahl 1989), with populations mostly limited in a bottomup manner by resources such as food or breeding sites (Newton 1979). Consistent with this view, traditional studies on interactions among sympatric raptors have focused on competition and resource partitioning (e.g. Herrera \& Hiraldo 1976, Reynolds et al. 1982, Jaksic \& Braker 1983, Bosakowski et al. 1992).

The idea that birds of prey may frequently kill each other was initially suggested by reviews of raptor diets that focused on the occurrence of raptorial

*Corresponding author.

Email: fsergio@ebd.csic.es

Conflict of interests: The authors declare no conflict of interests. species as prey items (e.g. Mikkola 1976, 1983, Voous 1988). For example, Mikkola (1976, 1983) compiled data on 2863 cases in which birds of prey appeared in the diet lists of other birds of prey species. These studies were fundamental in highlighting how raptors may be more subject to predation than previously thought, but they did not quantify the effect size or population impact of such predation. They simply showed that predation among raptors occurs, with unknown consequences for the population of the victim species. For years to come, such events were still mostly treated as exceptional anomalies (e.g. Rohner \& Doyle 1992, Ellis et al. 1999, Byshnev 2002).

In the 1980s, the apparent dichotomy between competition and predation was partly reconciled by the concept of intraguild predation, defined as the killing of species that use similar resources, and portrayed as an extreme form of interference competition (reviewed in Polis et al. 1989, Polis \& Holt 1992). Such a new approach was important because, 
within a competition scenario, it switched emphasis to the death risk exerted by one of the competitors on the other, or by both the competitors on each other. This is important because there is large consensus that the selective pressure operated by predation is usually more direct and stronger than the one imparted by competition (e.g. Sih et al. 1985, Polis et al. 1989, Lima \& Dill 1990): individuals may often cope with competition by paying limited fitness costs but, by definition, they cannot survive predation. In particular, predators can affect individual fitness and population and community processes through lethal effects (direct consumption or 'density' effects), where prey is consumed, or through non-lethal effects (traitmediated effects or interactions), where behavioural compensation to predation risk occurs, such as animals avoiding areas of high predation risk (Abrams 1984, Lima 1998, Agrawal 2001). Studies of invertebrates, fish and amphibians have shown that non-lethal effects may be larger than lethal effects in determining the behaviour, condition, density and distribution of animals over a range of trophic levels (Werner \& Peacor 2003, Preisser et al. 2005). Therefore, the existence of even incidental predation between raptors may mean that there is a profound effect on the behaviour, population dynamics and community structure mediated through non-lethal effects (reviewed in Cresswell 2008).

Since its conceptualization, studies on intraguild predation have proliferated and the phenomenon has been demonstrated, both empirically and experimentally, to be a fundamental determinant of the structure of predator assemblages of invertebrates, fish and mammalian carnivores (reviewed by Polis \& Holt 1992, Palomares \& Caro 1999, Arim \& Marquet 2004). Strangely, research on intraguild predation in birds of prey has been scarce, suggesting a need for more emphasis on this overlooked field in investigations of these much studied species.

Here we provide a review of quantitative studies that tested the effect of intraguild predation on raptorial species. Hereafter, we use the term 'raptor' to refer to both diurnal and nocturnal birds of prey.

\section{LITERATURE SEARCHES AND RATIONALE}

We included in our review all studies on interactions among potentially competing species in which at least one of the species is known, even occasionally, to kill the other(s). In most cases, the authors of the studies reported the predation events that they recorded or that are published in the literature. When they did not explicitly address such issues, we examined the relevant literature on such species and the compiled lists of predation on raptors (e.g. Uttendörfer 1952, Mikkola 1976, 1983, Voous 1988, Serrano 2000). Therefore, we also included some studies that were not originally framed by the authors as intraguild predation but where both the predation and the competition components were clear (e.g. Kostrzewa 1991, Hakkarainen \& Korpimäki 1996). In a few cases, the degree of competition between the killer and victim species may have been weak (e.g. Northern Goshawks Accipiter gentilis preying on Common Kestrels Falco tinnunculus in Petty et al. 2003). We included such studies only when the authors framed the relationship as a potential case of intraguild predation, or when the competition component was simply difficult to assess (e.g. potentially evident only in years of low prey availability).

Papers on the subject were collected as follows: (1) we conducted searches of electronic literature databases (Web of Science and the Zoological Record) entering as keywords the following six terms intraguild, intraguild predation, interference, competition, interaction, predation; (2) we repeated the searches by combining each of the above terms with the following keywords - bird of prey, eagle, falcon, harrier, hawk, kite, osprey, owl, raptor; and (3) we looked for further relevant papers cited in the initial batch of publications found through the electronic searches. Further papers were brought to our attention by colleagues.

During the above searches, we discounted studies that exclusively focused on dietary lists because evidence of predation among raptors is already well known and because we were more interested in reviewing the potential impact of intraguild predation on the behaviour, individual fitness and population dynamics of the victim species. We also discounted studies that only reported resource partitioning without a clear reference to the impact of one species on the other(s), such as studies analysing differential habitat or prey use by sympatric raptors. This is because such studies do not help in understanding whether resource partitioning was a response to the presence of the other guild member or whether it emerged as independent selection of different resources by the two species.

For each study included in the review, we report the species involved and the type of impact of the killer species upon its victim. Below, for clarity of presentation, effects are grouped into four broad 

Table 1. Effect of intraguild predation risk on territory occupancy and breeding performance of the individuals of the victim species.

\begin{tabular}{|c|c|c|c|c|}
\hline \multirow[b]{2}{*}{ Killer species } & \multirow[b]{2}{*}{ Victim species } & \multicolumn{2}{|c|}{ Effect of intraguild predation on: } & \multirow[b]{2}{*}{ Reference } \\
\hline & & Occupancy & Breeding success & \\
\hline Northern Goshawk & Red Kite & & 0 & Dobler (1990) \\
\hline Northern Goshawk & Common Buzzard & 1 & 1 & Kostrzewa (1991) \\
\hline Northern Goshawk & Common Buzzard & 1 & 1 & Krüger (2002) \\
\hline Northern Goshawk & Common Buzzard & 1 & 1 & Hakkarainen et al. (2004) \\
\hline Northern Goshawk & Honey Buzzard & & 1 & Kostrzewa (1991) \\
\hline Northern Goshawk & Honey Buzzard & 0 & 0 & Hakkarainen et al. (2004) \\
\hline Golden Eagle & Peregrine Falcon & & 0 & Gainzaraian (2000) \\
\hline Golden Eagle & Peregrine Falcon & & 0 & Sergio et al. (2004) \\
\hline Eagle Owl & Peregrine Falcon & & 0 & Gainzaraian (2000) \\
\hline Eagle Owl & Peregrine Falcon & & 0 & Sergio et al. (2004) \\
\hline Eagle Owl & Peregrine Falcon & & 1 & Brambilla et al. (2006b) \\
\hline Eagle Owl & Black Kite & 1 & 1 & Sergio et al. (2003a), Sergio and Newton (2003) \\
\hline Eagle Owl & Black Kite & 0 & 1 & Sergio et al. (2003a) \\
\hline Eagle Owl & Black Kite & 0 & 0 & Sergio et al. (2003a) \\
\hline Eagle Owl & Black Kite & 1 & 0 & Sergio et al. (2003a) \\
\hline Eagle Owl & Black Kite & 1 & 0 & Sergio et al. (2003a) \\
\hline Eagle Owl & Black Kite & 1 & 1 & Sergio et al. (2003a) \\
\hline Eagle Owl & Black Kite & 1 & 1 & Sergio et al. (2003a) \\
\hline Eagle Owl & Northern Goshawk & & 1 & Busche et al. (2004) \\
\hline Eagle Owl & Tawny Owl & & 1 & Sergio et al. (2007) \\
\hline Eagle Owl & Tengmalm's Owl & 0 & 0 & Hakkarainen and Korpimäki (1996) \\
\hline Ural Owl & Tengmalm's Owl & 1 & 1 & Hakkarainen and Korpimäki (1996) \\
\hline Barred Owl & Spotted Owl & 1 & & Kelly et al. (2003) \\
\hline Barred Owl & Spotted Owl & 1 & & Pearson and Livezey (2003) \\
\hline Barred Owl & Spotted Owl & 1 & 1 & Olson et al. $(2004,2005)$ \\
\hline Barred Owl & Spotted Owl & 1 & & Olson et al. $(2004,2005)$ \\
\hline Barred Owl & Spotted Owl & 1 & & Olson et al. $(2004,2005)$ \\
\hline Various* & Little Owl & & 0 & Tomé et al. (2004) \\
\hline Various* & Little Owl & & 0 & Tomé et al. (2004) \\
\hline
\end{tabular}

1 = significant relationship; 0 = non-significant relationship; empty cell = not tested.

*Includes various species, such as mustelids, foxes, rats and Jewelled Lizards Lacerta lepida.

categories: (1) demographic effects at the level of the individual - this included cases in which intraguild predation risk was shown to affect territory occupancy, breeding success, survival probability, age or individual quality; (2) behavioural effects at the level of the individual - when the risk of intraguild predation led to spatial or temporal avoidance of the killer, changes in habitat selection, breeding dispersal towards safer sites, short-term anti-predatory behavioural responses (e.g. lower vocal activity by owls exposed to predation risk) or alterations of social behaviour; (3) populationlevel effects, including impacts on population-level density and breeding performance; and (4) effects on whole raptor assemblages.

\section{REVIEW OF PUBLISHED STUDIES}

Overall, we found 39 studies that could be classified as tests of intraguild predation effects (Tables 1-3).
These included 63 populations belonging to 11 killer species and 15 victim species. In matched comparisons and when considering only studies that reported a significant intraguild predation impact in Tables 1-3, killer species were on average more than three times heavier than their victims (matched pairs $t$-test: $t_{12}=3.83, P=0.002$; Fig. 1 ), which agrees with earlier assessments on invertebrates and carnivores (Polis et al. 1989, Palomares \& Caro 1999). In fact, in all cases the killer species was larger than its victim (Fig. 2). The linear relationship between the body mass of the killer and victim species was only marginally significant (Spearman's rank correlation coefficient $r_{\mathrm{s}}=0.52, P=0.064$; Fig. 2). Finally, the minimum observed ratio between the body mass of a killer species and the mass of its demonstrated victim was 1.13 , suggesting that predation effects may disappear for pairs of similar sized species. 
Table 2. Behavioural responses by individuals of the victim species when exposed to the risk of intraguild predation.

\begin{tabular}{|c|c|c|c|c|c|}
\hline \multirow[b]{2}{*}{ Killer species } & \multirow[b]{2}{*}{ Victim species } & \multicolumn{3}{|c|}{ Effect of intraguild predation on: } & \multirow[b]{2}{*}{ Reference } \\
\hline & & $\begin{array}{c}\text { Spatial } \\
\text { avoidance* }\end{array}$ & $\begin{array}{l}\text { Habitat } \\
\text { selection† }\end{array}$ & $\begin{array}{c}\text { Short-term } \\
\text { behavioural } \\
\text { response }\end{array}$ & \\
\hline Northern Goshawk & Common Buzzard & & 1 & 1 & Krüger (2002) \\
\hline Golden Eagle & Peregrine Falcon & 0 & & & Sergio et al. (2004) \\
\hline Golden Eagle & Peregrine Falcon & 1 & & & Gainzaraian et al. (2000) \\
\hline Golden Eagle & Peregrine Falcon & 1 & & & Fielding et al. (2003) \\
\hline Golden Eagle & Common Buzzard & 1 & & & Fielding et al. (2003) \\
\hline Various raptors§ & Lesser Kestrel Falco naumanni & 1 & & & Tella et al. (2004) \\
\hline Eagle Owl & Black Kite & 1 & 1 & & Sergio et al. (2003a, 2003b) \\
\hline Eagle Owl & Black Kite & 1 & & & Sergio et al. (2003a) \\
\hline Eagle Owl & Black Kite & 0 & & & Sergio et al. (2003a) \\
\hline Eagle Owl & Black Kite & 1 & & & Sergio et al. (2003a) \\
\hline Eagle Owl & Black Kite & 1 & & & Sergio et al. (2003a) \\
\hline Eagle Owl & Black Kite & 1 & & & Sergio et al. (2003a) \\
\hline Eagle Owl & Black Kite & 1 & & & Sergio et al. (2003a) \\
\hline Eagle Owl & Peregrine Falcon & 0 & & & Gainzaraian (2000) \\
\hline Eagle Owl & Peregrine Falcon & 0 & & & Sergio et al. (2004) \\
\hline Eagle Owl & Peregrine Falcon & 0 & & & Brambilla et al. (2006a) \\
\hline Eagle Owl & Tengmalm's Owl & 0 & & & $\begin{array}{l}\text { Hakkarainen and } \\
\text { Korpimäki (1996) }\end{array}$ \\
\hline Ural Owl & Tengmalm's Owl & 1 & & & $\begin{array}{l}\text { Hakkarainen and } \\
\text { Korpimäki (1996) }\end{array}$ \\
\hline Great Horned Owl & Spotted Owl & & & 0 & Crozier et al. (2005) \\
\hline Barred Owl & Spotted Owl & & & 1 & Crozier et al. (2006) \\
\hline Pine Marten Martes martes & Tengmalm's Owl & & 1 & 1 & Sonerud (1985) \\
\hline Pine Marten & Northern Hawk Owl & & 1 & 1 & Sonerud (1985) \\
\hline Pine Marten & Pygmy Owl & & 1 & 0 & Sonerud (1985) \\
\hline Barn Owl & Little Owl & & & 1 & Zuberogoitia et al. (2007) \\
\hline Various $\mathbb{1}$ & Little Owl & 1 & & & Tomé et al. (2004) \\
\hline Various $\mathbb{1}$ & Little Owl & 0 & & & Tomé et al. (2004) \\
\hline
\end{tabular}

1 = significant relationship; $0=$ non-significant relationship; empty cell $=$ not tested.

*Selection of breeding sites further away from the potential killer than available.

†Risk-sensitive habitat selection.

ҒImmediate behavioural response to the visual or acoustic detection of a potential intraguild predator (e.g. reduced vocal activity or escape to refugia after predator detection).

SIncludes various raptorial species: Saker Falcon Falco cherrug, Peregrine Falcon, Golden Eagle, Steppe Eagle Aquila nipalensis, Long-legged Buzzard Buteo rufinus and Eagle Owl.

IIncludes various species, such as mustelids, foxes, rats and Jewelled Lizards Lacerta lepida.

\section{Demographic effects at the level of the individual}

\section{Effect on territory occupancy}

Proximity to an intraguild predator increased the probability of territory abandonment and depressed the rate of territory occupation in 14 populations of the 18 for which the relationship was tested ( Table 1). The relationship was very consistent across populations of the same species studied at distant locations: for example, independently of the study area involved, Northern Goshawks and Barred Owls Strix varia consistently affected the territory occupation rate of Common Buzzards Buteo buteo and Spotted Owls Strix occidentalis, their respective victim species. The negative impact was also consistent whether the comparison was temporal (occupation rate of the victim before and after the settlement of the intraguild predator nearby, e.g. Kelly et al. 2003) or spatial (occupation rate of territories with and without a potential intraguild killer nearby, e.g. Olson et al. 2005, or change in occupancy rates along a continuum of distances to the potential killer, e.g. Sergio \& Newton 2003). 
Table 3. Population-level effects of intraguild predation in raptorial species: correlations between the abundance of the intraguild killer and the density and productivity of the victim species.

\begin{tabular}{|c|c|c|c|c|}
\hline \multirow[b]{2}{*}{ Killer species } & \multirow[b]{2}{*}{ Victim species } & \multicolumn{2}{|c|}{ Effect on victim } & \multirow[b]{2}{*}{ Reference } \\
\hline & & Density & $\begin{array}{l}\text { Breeding } \\
\text { success }\end{array}$ & \\
\hline Northern Goshawk & Common Kestrel & 1 & & Petty et al. (2003) \\
\hline Northern Goshawk & Tawny Owl & 0 & & Petty et al. (2003) \\
\hline Northern Goshawk & Long-eared Owl Asio otus & 0 & & Petty et al. (2003) \\
\hline Northern Goshawk & Short-eared Owl Asio flammeus & 0 & & Petty et al. (2003) \\
\hline Great Horned Owl & Red-tailed Hawk Buteo jamaicensis & 0 & & Mclnvaille and Keith (1974) \\
\hline Eagle Owl & Black Kite & 1 & 1 & Sergio et al. (2003a) \\
\hline Eagle Owl & Common Buzzard & 1 & & Sergio et al. (2005a) \\
\hline Eagle Owl & Northern Goshawk & 1 & & Busche et al. (2004) \\
\hline Eagle Owl & Tawny Owl & 1 & & Sergio et al. (2007) \\
\hline Barred Owl* & Spotted Owl* & & $0 *$ & Anthony et al. (2006) \\
\hline
\end{tabular}

1 = significant relationship; $0=$ non-significant relationship; empty cell $=$ not tested.

*Includes data from 14 populations. In all cases, the effect on breeding success was not significant.

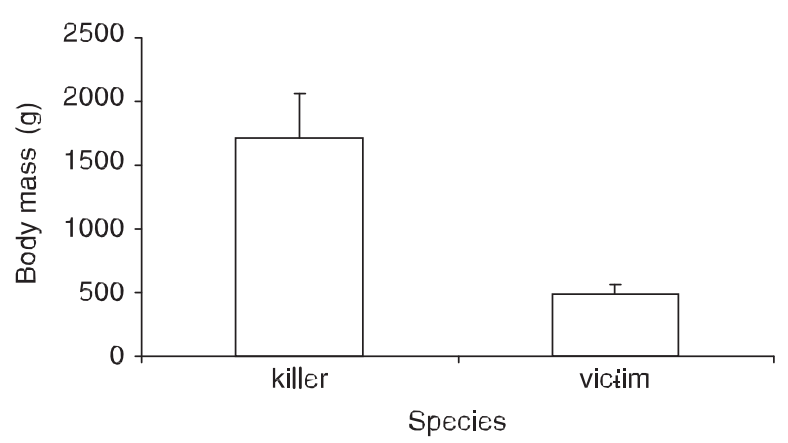

Figure 1. Body mass of raptorial victim species and of their raptorial intraguild predator in 13 matched comparisons. Only cases in which a significant intraguild predation effect was shown in Tables 1-3 were included. Body masses were taken from Cramp and Simmons (1980) and König (1999).

A significant impact on occupancy rates was also shown by an elegant experiment: Hakkarainen and Korpimäki (1996) erected nestboxes for Tengmalm's Owls Aegolius funereus so as to manipulate their exposure to two potential intraguild predators, the Eagle Owl Bubo bubo and the Ural Owl Strix uralensis, while simultaneously controlling for territory quality. Boxes located close to Ural Owls were rarely used and their occupation rate was lower than at control sites. In contrast, the effect of proximity to Eagle Owls (which prey on Ural Owls) was not significant.

\section{Effect on breeding success}

Impact of intraguild predation on breeding success was tested for 23 populations belonging to eight

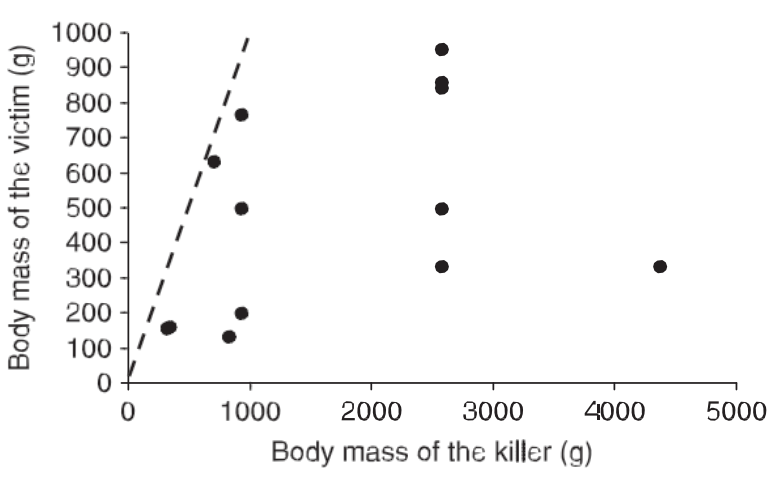

Figure 2. Relationship between the body masses of raptorial victim species and of their raptorial intraguild predator (data sources as in Fig. 1). Body masses were taken from Cramp and Simmons (1980) and König (1999). The dotted line depicts the nil expectation of equal body size between the killer and the victim.

victim species (Table 1). Significant effects were found in almost $60 \%$ of the tests. Again, results tended to be consistent within species across distant populations (e.g. similar impact of Northern Goshawks on Common Buzzards in different parts of Germany and in Finland: Kostrzewa 1991, Krüger 2002, Hakkarainen et al. 2004).

A significant impact was also demonstrated by a convincing experiment: Krüger (2002) presented a dummy Northern Goshawk accompanied by Northern Goshawk playback calls to Common Buzzard pairs. Compared with control pairs, those exposed to the 'Goshawk treatment' had higher rates of nest desertion and breeding failure. Results of this experiment were consistent with the idea that Common Buzzards 
perceived Northern Goshawks as predators rather than simple competitors (Krüger 2002).

\section{Survival}

Only one study provided a quantitative capturerecapture analysis of the impact of the killer species on the survival of the victim (Anthony et al. 2006). The results suggested that in nine of 14 monitored populations the survival rates of Spotted Owls declined with increasing abundance of Barred Owls. However, the effect was generally weak and only considered relevant in two, possibly three, populations. The authors suggested that such mixed results may have had two causes. First, the abundance of the killer was estimated for each study area in a coarse manner, as the percentage of territories of the victim species co-occupied by the killer. Secondly, the killer species was in the process of expansion into the range of the victim species and its occurrence was still low in many of the sample populations, leading to an expectedly low impact. In agreement with the latter observation, pronounced effects on survival were noted only in three populations in which Barred Owls were already well established and locally abundant.

Apart from the above study, we are not aware of others that have explicitly tested the impact of exposure to an intraguild predator on survival probabilities, but many of the reported survival rates for raptors are likely to incorporate direct and indirect mortality as a consequence of predation and avoidance of predation by other raptors. Some studies have reported high predation rates on raptor nestlings or on young raptors in the post-fledging period, as assessed by telemetry. For example, Sunde (2005) reported that $42 \%$ of 131 Tawny Owl Strix aluco fledglings died during the post-fledging period. Of such mortality, $80 \%$ was caused by predation $(47 \%$ by raptors and $33 \%$ by mammalian carnivores). Therefore, post-fledging mortality in this population was essentially dictated by predation rates. Furthermore, in this population predation rates varied from 0 to $50 \%$ as a function of fledging date and independently of nestling body condition. The author suggested that high predation rates on late fledglings could cause Tawny Owls to refrain from breeding in years when low prey availability prevented them from laying early enough to escape the seasonal peak of predation on their fledglings (Sunde 2005). Such temporal dynamics illustrate the complex nature and potential indirect effects of intraguild predation.

In another study, Petty et al. (2003) estimated that the Northern Goshawk population that they studied killed every year 115 Common Kestrels in an area which contained about seven Kestrel breeding pairs. This suggested that Northern Goshawks had the potential to remove all breeders and possibly all floaters of the local study site, which very probably acted as a sink patch. Other authors have reported high predation rates on raptor nestlings, fledglings or dispersing young (e.g. Luttich et al. 1971, McInvaille \& Keith 1974, Sonerud 1985, Rohner \& Hunter 1996, Sergio et al. 2005a).

These studies show how important anti-predatory decisions may be for many raptorial species. Unfortunately, none of them assessed whether the probability of predation or survival declined with increasing exposure to a potential intraguild predator at the individual territory level, even though the latter is the most pertinent scale of analysis to detect such effects (see Anthony et al. 2006). Also, it is often difficult to understand to what degree predation was the ultimate or proximate cause of death. For example, Rohner and Hunter (1996) showed that survival rates of fledgling Great Horned Owls Bubo virginianus declined from about 0.8 during years of peak availability of cyclic hares (the main prey of Great Horned Owls and of their potential predators) to 0.2 in years of low hare availability. The decline in survival was accompanied by a parallel rise in mortality by predation, probably triggered by low food availability for the Owls' intraguild predators, such as Lynx Lynx canadensis and Wolverines Gulo gulo.

\section{Age and individual quality}

We found only one study which tested whether sites associated with a higher risk of intraguild predation were occupied by lower quality individuals: Hakkarainen and Korpimäki (1996) showed that the nestboxes used by Tengmalm's Owls in proximity to Ural Owls were more likely to be occupied by young males and short-winged (i.e. young and subdominant) females than control boxes.

\section{Behavioural effects at the level of the individual}

These studies usually focus on the behavioural responses of individuals subject to different degrees of predation risk. They demonstrate how anti-predatory behaviours may be a common component of raptor ecology.

\section{Direct spatial avoidance}

Nine studies tested whether individuals of 19 populations of six victim species selected breeding sites so 
as to avoid their potential killer (Table 2). In 12 cases there was evidence of spatial avoidance, including the experimental manipulation by Hakkarainen and Korpimäki (1996).

\section{Temporal segregation}

A further way by which individuals of the victim species may respond to predation risk is by occupying time frames not used by the killer species, as demonstrated in some carnivores (e.g. Harrison et al. 1989, Arjo \& Pletcher 1999). We are not aware of studies that have quantitatively tested such relationship in raptors. Rudolph (1978) reported that when Barn Owls Tyto alba nested in proximity to Great Horned Owls, they behaved very elusively: they departed for their foraging trips from the nesting cliffs after the Great Horned Owls had already departed, they came back for day-roosting earlier (before dawn) and they became immediately silent each time that a Great Horned Owl appeared in the surroundings or started to vocalize. Unfortunately, these observations were only qualitative, but they do suggest that in some cases the individuals of the victim species may respond to predation risk by altering their activity times. By contrast, Jaksic (1982) argued that temporal partitioning is usually ineffective in promoting coexistence and resource partitioning in birds of prey, even among diurnal and nocturnal species. However, he did suggest that the occupation of the 'nocturnal-niche' by owls may have been influenced more by the need to minimize interference interactions with diurnal raptors than by the benefits of accessing an 'unexploited' resource.

\section{Habitat selection}

Few studies have tested whether intraguild predation risk could affect habitat selection by the victim species (Table 2). Sonerud (1985) showed that the distribution of two cavity-nesting owl species across habitats varied in parallel with the nest-predation pressure (mainly by mustelids) associated with each habitat type. No such relationship was found in a third owl species using cavities too small to be accessible to predators. Such results were consistent with the idea that the owls recognized variations in predation risk, and responded to it by avoiding dangerous habitats and preferring safer ones.

In another study, Tawny Owls were shown to overlap over one main prey item, the Edible Dormouse Glis glis, with their potential killer, the Eagle Owl (Sergio et al. 2007). In the study region, Dormice were habitat specialists associated with coppice woodland. Therefore, exploitation of a common resource was hypothesized to expose Tawny Owls to predation risk when hunting their preferred prey in coppice woodland. Consistent with a trade-off between foraging and predator-avoidance, the risky (but foodrich) habitat was preferred by Tawny Owls when these nested far from Eagle Owls, but avoided when in proximity to the killer. Furthermore, with increasing Eagle Owl density, Tawny Owls passed from ignoring the killer, to selecting sites far from it to avoiding risky habitats when in its proximity. This was consistent with the idea of a threshold density of the killer, beyond which predation refugia are too scarce and direct spatial avoidance impractical. Under this scenario, habitat-mediated avoidance may be one of the only mechanisms allowing coexistence.

A similar trade-off between foraging needs and predator avoidance was reported for the selection of diurnal roost sites by fledgling and dispersing Tawny Owls (Sunde et al. 2003). Finally, an analysis across seven study sites showed that the abundance of Eagle Owls depressed the profitability for Black Kites Milvus migrans of nesting near wetlands, their optimal foraging habitat (Sergio et al. 2003b). Overall, all the above demonstrates the complexity of the responses by the victim species to predation risk and the ability of the killer species to alter patterns of habitat quality for its victim.

\section{Breeding dispersal}

One experimental study showed that Tengmalm's Owls exposed to a simulated nest predation attempt by a caged American Mink Mustela vison were more likely to abandon their territory and move elsewhere in the following year than control individuals (Hakkarainen et al. 2001). In another experimental study, Common Buzzard pairs that failed a reproduction attempt because of experimental exposure to a Northern Goshawk dummy had a higher probability of moving to other nearby territories or disappear than control pairs (Krüger 2002). Finally, Black Kite individuals that suffered a breeding failure caused by predation were more likely to change territory the following year (Forero et al. 1999). These studies are important because they highlight one of the behavioural mechanisms that may generate risk-sensitive occupancy and predator avoidance.

\section{Short-term behavioural avoidance}

Probably, the simplest and most direct form of antipredator response is to flee from a predator when 
this is detected. We are aware of five studies that investigated the response of a raptorial species when confronted with a potential intraguild predator (Table 2). These included eight populations belonging to five victim and five killer species. In six out of eight cases the victim species exhibited some form of escape or defence behaviour. For example, radiotracked Little Owls Athene noctua became significantly more silent and fled to refuges in small cavities of trees or buildings after detection of a Barn Owl, their local predator (Zuberogoitia et al. 2007).

The five studies included three experimental ones. In the first, Krüger (2002) exposed Common Buzzard breeding pairs to a Northern Goshawk dummy accompanied by playback calls. Buzzards generally fled from the area and disappeared. In the second experimental study, Crozier et al. (2006) showed that the vocal responsiveness of Spotted Owls to conspecific calls declined immediately after exposing them to simulated calls of the dominant Barred Owl. This was consistent with the idea that Spotted Owls became more reluctant to call in the presence of a potential attacker. However, a similar experimental design with a different killer species gave different results; the calling behaviour of Spotted Owls was unaffected by previous playing of Great Horned Owl calls in their territory (Crozier et al. 2005). Unfortunately, as admitted by the authors, this study was weakened by two possible confounding factors: (1) the vocal responsiveness of Spotted Owls was tested $24 \mathrm{~h}$ after playing the killer calls, which may be too long a time-lag to detect a response; and (2) a high proportion of the tested Spotted Owl pairs already had Great Horned Owls nesting in their immediate vicinity, which may have confounded the experiment.

Overall, behavioural avoidance may limit the time and space available for hunting, exacerbating the effects of direct competition and leading to reduced foraging efficiency. This idea is supported by a recent experiment in which artificial larders for Pygmy Owls Glaucidium passerinum erected close to a potential competitor and killer contained less cached food than larders erected far from the killer (Suhonen et al. 2007).

\section{Sociality}

Only one study tested the effect of intraguild predation on social behaviour and showed that, compared with a random distribution, Black Kites avoided colonial nesting when close to their potential Eagle Owl killer and positively selected coloniality when breeding far from the killer (Sergio et al. 2003a). The authors suggested that the topographical dominance of Eagle Owl nest-sites coupled with the acoustic and visual detectability of Kite nests during prey deliveries made colonies easy predation targets for the Owls when these nested nearby (details in Sergio et al. 2003a). There was also evidence of an interaction with food availability: Kite coloniality increased with increasing food availability when far from Eagle Owls, but not when close to them.

\section{Population-level effects}

Seven studies tested the potential impact of intraguild predation at the population level (Table 3). These involved 23 populations belonging to four killer and 10 victim species. Most of these analyses were correlations between the population densities of the killer and victim species, calculated spatially across sites (Sergio et al. 2003a, 2005c, 2007) or temporally along a time-series within the same study plot (McInvaille \& Keith 1974, Petty et al. 2003, Anthony et al. 2006). In five cases the relationship was significantly negative. In one of them, the authors followed a Northern Goshawk population before and after the colonization of their study area by the killer species (Eagle Owls, Busche et al. 2004). They reported a rapid Goshawk decline, which started 2 years after the first breeding by the Owls in the region in 1988. By the year 2000, the Goshawk population was reduced to one-third of its precolonization numbers and most of the original Goshawk nests and territories were occupied by Eagle Owls.

Of the five cases of non-significant impact, three were owl species unaffected by predation by diurnal Northern Goshawks, probably because of a combination of their hunting style, habitat use and activity time (Petty et al. 2003). The fourth case was a 6-year study in which the impact of an increasing population of the killer species may have been masked by a parallel increase in the food supply for the victim species (McInvaille \& Keith 1974). The fifth case reported a lack of impact by Barred Owls on the population-level productivity of Spotted Owls within each of 14 study areas (Anthony et al. 2006). However, relationships may have been obscured by the coarse-scale estimate of Barred Owl occurrence and the fact that Barred Owls were very scarce in many of the study sites (Anthony et al. 2006).

Finally, in one study the authors found that variation across study plots in population density and productivity of the victim species (Black Kite) were related to the interaction between the density of the 
killer species (Eagle Owl) and food availability for the victim species (Sergio et al. 2003a). Black Kite density increased with food availability less steeply in areas with Eagle Owls than in areas without Owls, while Kite productivity increased with food availability in areas without Eagle Owls, but declined with increasing food availability in areas of high predation risk. Again, such results underline the complex nature and the potentially counterintuitive patterns generated by intraguild predation dynamics. Similarly, complex dynamics have been reported for other taxa (e.g. Sih et al. 1985, Peacor \& Werner 2004).

\section{Effects on the structure and diversity of raptor assemblages}

We are aware of only two studies that examined variations in assemblage structure in relation to intraguild predation pressure, both of them conducted in the Alps. In the first, the diversity of an assemblage of diurnal raptors peaked at medium to high densities of a major intraguild predator, the Eagle Owl (Sergio et al. 2003a), which is consistent with the predictions of various theoretical models (Holt \& Polis 1997, Diehl et al. 2000, Mylius et al. 2001). However, the relationship was not significant and the authors could not survey all the local species of diurnal raptors. In the second, the diversity of an assemblage of nocturnal raptors was positively related to Eagle Owl density (Sergio et al. 2007). The authors hypothesized that Eagle Owls may depress the density of aggressive mesopredators, such as Tawny Owls. Because the latter actively prey upon and compete with smaller owl species, the abundance of Eagle Owls may release predation and competition pressure on smaller owls, ultimately resulting in a more diverse assemblage. Both the above studies were based on simple correlations and should thus be interpreted with caution.

\section{DISCUSSION}

\section{The generality of intraguild predation}

Intraguild predation has been long overlooked in raptor studies for various reasons. First, surveying raptor species is notoriously time- and resource-demanding due to their low density and elusiveness. It follows that in many cases monitoring multiple raptor species simultaneously may be excessively taxing or logistically impractical. Secondly, much research on raptors has been conducted in Europe and North America. In these areas many of the largest raptor species have been extirpated or reduced so much in density that their impact on smaller raptors may be difficult to detect (although many of these species are now recolonizing previously occupied areas). Thirdly, intraguild predation effects may be subtle: they may become noticeable only during crashes of the main prey of the killer species (Rohner \& Doyle 1992, Tella \& Mañosa 1993, Rohner \& Hunter 1996, Serrano 2000), and they may frequently involve non-lethal effects. In the latter cases, the selective advantage of predator avoidance may have been so strong as to prevent the current coexistence of the killer and victim species (Cresswell 2008): demonstrating intraguild predation effects in these systems may be extremely difficult. Fourthly, predation events are often difficult to document. For example, breeding adults of the victim species may be killed far from their nest, where the event is likely to pass unnoticed, with a consequent breeding failure recorded as caused by unknown factors. Similarly, much predation may target recently fledged or dispersing young, whose fates are rarely known in standard surveys. In agreement with this, when large numbers of young have been radiotagged, high predation rates have sometimes been reported (e.g. Tawny Owls: 34\% of the tagged young killed by predators, Sunde 2005; Great Horned Owls: up to 32\%, Rohner \& Hunter 1996; Burrowing Owls Athene cunicularia: 23\%, Todd et al. 2003; Prairie Falcons Falco mexicanus: 14\%, MacFadzen \& Marzluff 1996). Most of these casualties would have been missed by a standard monitoring scheme focusing on nest-density and breeding success. Finally, even when observed predation rates are low, this does not necessarily imply that predation pressure is irrelevant (Lima \& Dill 1990, Abrams 1993, 1994, Cresswell 2008). For example, predation rates may be low because of the effectiveness of predator avoidance, which may ultimately limit the habitat available to the victim species (Palomares \& Caro 1999, Creel et al. 2001, Cresswell 2008). Consistent with this idea, low nest predation rates by the killer species have been reported in studies that nonetheless detected marked impacts of the killer species on the density, occupancy and breeding success of its raptor victim (e.g. Hakkarainen \& Korpimäki 1996, Krüger 2002, Sergio et al. 2003a). All the above confirms the recognized, subtle nature of intraguild predation (Polis et al. 1989, Palomares \& Caro 1999). In-depth knowledge of the study species and setting-up a priori hypotheses of the potential impact by local, larger predators may be valid avenues to curtail the risk of overlooking intraguild predation as an important limiting factor. 
Despite the subtle and complex nature of intraguild predation, our review suggested that it may be a widespread, size-based phenomenon in raptor assemblages. Studies reporting significant impacts spanned a wide range of empirical and experimental methodologies, of diurnal and nocturnal study species, of individual and population-level effects, and of demographic impacts by the killer and anti-predator responses by the victim. Such an observation confirms the previous notion, mostly based on studies of invertebrates, of intraguild predation as a common feature of most communities (e.g. Polis et al. 1989, Polis \& Holt 1992). For example, Arim and Marquet (2004) demonstrated that intraguild predation occurred in $58-87 \%$ of the trophic groups that they analysed. Furthermore, their quantitative analysis of 113 food webs showed that some species were more likely than others to engage in intraguild predation dynamics depending on their position in the food pyramid. For example, top predatory species were less likely to be intraguild victims than expected by chance. The results of Arim and Marquet (2004) supported the idea that the intraguild killer may frequently exclude the intraguild victim, as predicted by various theoretical models (e.g. Holt \& Polis 1997, Mylius et al. 2001). The large list of impacts on raptor species that we reported are consistent with this.

If the costs of intraguild predation and the necessity of an anti-predator response were often clear for the victim species in the reviewed studies, the benefits for the killer were usually not quantitatively examined. Killing of a competitor may be triggered by different motivations. First, it may free resources for the killer, such as food or nest-sites. For example, some large owls (e.g. Eagle Owls) are locally dependent on large stick-nests for breeding and readily take over those originally built by diurnal raptors (e.g. Northern Goshawks, Common Buzzards). This may be accompanied by killing of the original nest owner, or the victim individuals may abandon the area because of the risk of breeding in close proximity of their potential predator (e.g. Orians \& Kuhlman 1956, McInvaille \& Keith 1974, Busche et al. 2004). In this scenario, perhaps common where nest-site availability is limiting, intraguild predation effects are triggered by exploitation competition and by an indirect effect of predation risk. Similar usurpation of nest platforms may also occur between diurnal raptors that need large nests (e.g. Kostrzewa 1991, Krüger 2002, Hakkarainen et al. 2004). Secondly, killing of an intraguild competitor may lower the potential predation pressure on the offspring of the killer species (in cases of 'asymmetrical intraguild predation', sensu Palomares \& Caro 1999). Finally, killing events may simply represent opportunistic predation to acquire food. Consistent with this idea, predation rates and predation events have been linked in some cases to crashes in the availability of the main prey of the killer species, leading to widened diet breadth of the killer and a switch to alternative, secondary prey, such as raptors (Rohner \& Doyle 1992, Tella \& Mañosa 1993, Rohner \& Hunter 1996, Serrano 2000). Under this scenario, which is considered by some as the most common intraguild predation pathway, the killer does not actively attempt to remove a competitor but simply treats it as another prey item, opportunistically captured under food-stress conditions. However, this cannot explain why in some circumstances the killed victim is not consumed (Mikkola 1976). Finally, recent research suggests that consumption of species of higher trophic levels may yield different nutrients than predation upon species of lower trophic levels (Matsumura et al. 2004), adding a further dimension to the potential motivations and benefits for the killer. In this context, it would be particularly useful for future investigations to test: (1) whether the killed victims are consumed or not by the predator, (2) whether consumption rates of intraguild prey are comparable or not with those of non-intraguild prey (e.g. Sunde et al. 1999) and (3) whether different predation rates by a killer species on various, sympatric victim species are related to the potential degree of resource-overlap between the killer and the victims.

\section{Limitations and ways forward}

Despite the numerous studies that have reported significant effects (Table 1), this field of research is still in its infancy for raptor investigations. Most of the investigations have been published in the last 510 years. In particular, many studies have focused on the same species, such as Eagle Owls or Northern Goshawks. This may have been prompted by early reviews of diet lists that pointed out certain species as being more frequently associated than others with predation on other raptors (Mikkola 1976, 1983). Alternatively, these species may be for some reason more 'aggressive' than others towards other raptors, or they may be fortuitously associated with certain kinds of impacts that are easier to detect (e.g. killings associated with usurpation of a nest are easier to record than killings of dispersing young). Overall, despite the interest of the consistency of results across multiple studies on the same species at disparate locations, there is a need for research on as many 
different species as possible, in order to understand the generality of the phenomenon. Similarly, all the studies that we reviewed were from temperate or boreal regions of the northern hemisphere. Data from tropical areas and more saturated or pristine raptor assemblages would be extremely valuable. Recent data on carnivores suggest that the potential for competitive and predatory interactions may be much higher in these regions than in the impoverished communities of much of the northern hemisphere (Caro \& Stoner 2003).

Finally, most research conducted so far is highly correlative and the lack of proper experiments makes the distinction between cause and effect often fuzzy. For example, it is often unclear whether spatial avoidance of the killer by the victim is caused: (1) by an active recognition of predation risk and a consequent anti-predatory choice of the individuals of the victim species, or (2) by selective removal by the killer of victim individuals making the wrong decisions (i.e. a behavioural strategy as opposed to a natural selection process; Sergio et al. 2003a, 2007). Longitudinal analyses of the mortality, turn-over, behavioural plasticity and breeding dispersal of marked individuals subject to different levels of predation risk would yield much insight into such doubts. Clearly, more experimental investigations such as those by Hakkarainen and Korpimäki (1996), Krüger (2002) and Crozier et al. (2006) would be highly desirable. Reintroductions and spontaneous colonizations could also be exploited to compare population responses by the victim species through 'natural' experiments.

\section{Conservation implications}

Intraguild predation dynamics in vertebrate predators may present special conservation dilemmas because both the killer and the victim species are frequently endangered or protected (Roemer et al. 2002, Courchamp et al. 2003, Gutiérrez et al. 2007). For example, large Bubo owls have been frequently pointed out as a potential limiting factor for the success of reintroduction programmes of Peregrine Falcons Falco peregrinus and for the recovery of their wild populations after the DDT crash of the 1950s and 1960s (e.g. Cugnasse 1984, Cade et al. 1988). However, some of these owl populations were also extremely endangered or themselves the result of reintroduction programmes (e.g. Radler \& Bergerhausen 1988, Busche et al. 2004). In vertebrates, intraguild predation has been implicated in the failure of at least one carnivore reintroduction project (Scheepers \& Venzke 1995) and should clearly be taken more into consid- eration during the preliminary, planning stages of a reintroduction. Along the same line, reintroduction of potential killer species should be accompanied by an assessment of its potential impact on other local, endangered raptors.

On the other hand, intraguild predation may lead to mesopredator limitation, with potential positive effects on the prey species of the mesopredator (e.g. Palomares et al. 1995, Crooks \& Soulé 1999, Roemer et al. 2002). Such 'three trophic-level effects' could be used as conservation tools to enhance the populations of game species when these are limited by mesopredators (e.g. Palomares et al. 1995, Rogers \& Caro 1998, Müller \& Brodeur 2002). Finally, a scarcely explored field of research is the potential for intraguild predation to affect biodiversity and structure whole communities by triggering trophic cascades and by increasing environmental heterogeneity through its spatially heterogeneous effect on mesopredators (e.g. Ray et al. 2005 and references therein). Consistent with this idea, the diversity of an owl assemblage was shown to be tightly correlated with the abundance of a top predatory owl (Sergio et al. 2007) and, in the same region, raptor presence was shown to be a reliable surrogate of overall biodiversity value (Sergio et al. 2005b, 2006). Given its potential conservation relevance, more research on such relations would be highly welcomed.

We thank J. Quinn, J. Reynolds and R. Bradbury for organizing the BOU workshop and inviting us. We thank D. Potts for inviting us to a workshop on intraguild predation within the 28th Congress of the International Union of Game Biologists of Uppsala, which favoured further exchange of ideas on the topic. W. Cresswell, J. Quinn, P. Sunde, J. Wilson and an anonymous referee provided constructive comments on a previous draft of the paper. E. Korpimäki, R.J. Gutiérrez, P. Whitfield and I. Zuberogoitia kindly pointed out useful references and made available to us some of their still unpublished papers.

\section{REFERENCES}

Abrams, P.A. 1984. Foraging time optimization and interactions in food webs. Am. Nat. 124: 80-96.

Abrams, P.A. 1993. Why predation rate should not be proportional to predator density. Ecology 74: 726-733.

Abrams, P.A. 1994. The fallacies of 'ratio-dependent' predation. Ecology 75: 1842-1850.

Agrawal, A.A. 2001. Phenotypic plasticity in the interactions and evolution of species. Science 294: 321-326.

Anthony, R.G., Forsman, K.P., Franklin, A.B., Anderson, D.R., Burnham, K.P., White, G.C., Schwarz, C.V., Nichols, J.D., Hines, J.E., Owen, G.S., Ackers, S.H., Andrews, L.S., Biswell, B.L., Carlson, P.C., Diller, L.V., Dugger, K.M., 
Fehring, K.E., Fleming, T.L., Gerhardt, R.P., Gremel, S.A., Gutiérrez, R.J., Happe, P.J., Herter, D.R. \& Higley, J.M. 2006. Status and trends in demography of Northern Spotted Owls, 1995-2003. Wildl. Monogr. 163: 1-48.

Arim, M. \& Marquet, P.A. 2004. Intraguild predation: a widespread interaction related to species biology. Ecol. Lett. 7: 557-564.

Arjo, W.M. \& Pletcher, D.H. 1999. Behavioral responses of coyotes to wolf recolonization in northwestern Montana. Can. J. Zool. 77: 1919-1927.

Bosakowski, T., Smith, D.G. \& Speiser, R. 1992. Niche overlap of two sympatric-nesting hawks Accipiter spp. in the JerseyNew York highlands. Ecography 15: 358-372.

Brambilla, M., Rubolini, D. \& Guidali, F. 2006a. Factors affecting breeding habitat selection in a cliff-nesting Peregrine Falco peregrinus population. J. Ornithol. 147: 428-435.

Brambilla, M., Rubolini, D. \& Guidali, F. 2006b. Eagle Owl Bubo bubo proximity can lower productivity of cliff-nesting Peregrines Falco peregrinus. Ornis Fennica 83: 20-26.

Busche, G., Raddatz, H. J. \& Kostrzewa, A. 2004. NistplatzKonkurrenz und Prädation zwischen Uhu (Bubo bubo) und Habicht (Accipiter gentilis): erste Ergebnisse aus Norddeutschland. Die Vogelwarte 42: 169-177.

Byshnev, I.I. 2002. Interesting case of aggressive interaction between Common Buzzard (Buteo buteo) and Ural Owl (Strix uralensis). Subbuteo 5: 46.

Cade, T.J., Enderson, J.H., Thelander, C.G. \& White, C.M. (eds) 1988. Peregrine Falcon Populations: Their Management and Recovery. Boise: The Peregrine Fund.

Caro, T. M. \& Stoner, C. J. 2003. The potential for interspecific competition among African carnivores. Biol. Conserv. 110: 67-75.

Courchamp, F., Woodroffe, R. \& Roemer, G. 2003. Removing protected populations to save endangered species. Science 302: 1532.

Cramp, S. \& Simmons, K.E.L. (eds) 1980. The Birds of the Western Palearctic, Vol. 2. Oxford: Oxford University Press.

Creel, S., Spong, G. \& Creel, N. 2001. Interspecific competition and the population biology of extinction-prone carnivores. In Gittleman, J.L., Funk, S.M., MacDonald, D. \& Wayne, R.K. (eds) Carnivore Conservation: 35-60. Cambridge: Cambridge University Press.

Cresswell, W. 2008. Non-lethal effects of predation in birds. Ibis 150: 3-17.

Crooks, K.R. \& Soulé, M.E. 1999. Mesopredator release and avifaunal extinctions in a fragmented system. Nature 400: 563-566.

Crozier, M.L., Seamans, M.E. \& Gutiérrez, R.J. 2005. The effect of broadcasting Great Horned Owl vocalizations on Spotted Owl vocal responsiveness. J. Raptor Res. 39: 111-118.

Crozier, M.L., Seamans, M.E., Gutiérrez, R.J., Loschl, P.J., Horn, R.B., Sovern, S.G. \& Forsman, E.D. 2006. Does the presence of Barred Owls suppress the calling behaviour of Spotted Owls? Condor 108: 760-769.

Cugnasse, J. 1984. Le Faucon pélerin Falco peregrinus dans le sud du Massif Central de 1974 à 1983. Alauda 52: 161-176.

Diehl, S., Cooper, S.D., Kratz, K.W., Nisbet, R.M., Roll, S.K., Wiseman, S.W. \& Jenkins, T.M. 2000. Effects of multiple, predator-induced behaviors on short-term producer-grazer dynamics in open systems. Am. Nat. 156: 293-313.

Dobler, G. 1990. Brutbiotop und Territorialität bei Habicht (Accipiter gentilis) und Rotmilan (Milvus milvus). J. Ornithol. 131: 85-93.
Ellis, D.H., Tsengeg, P., Whitlock, P. \& Ellis, M.H. 1999. Predators as prey at a Golden Eagle Aquila chrysaetos eyrie in Mongolia. Ibis 141: 139-158.

Fielding, A.H., Haworth, P.F., Morgan, D.H., Thompson, D.B.A. \& Whitfield, D.P. 2003. The impact of Golden Eagles on a diverse bird of prey assemblage. In Thompson, D.B.A., Redpath, S.M., Fielding, A.H., Marquiss, M. \& Galbraith, C.A. (eds) Birds of Prey in a Changing Environment: 221-244. Edinburgh: The Stationery Office.

Forero, M.G., Donázar, J.A., Blas, J. \& Hiraldo, F. 1999. Causes and consequences of territory change and breeding dispersal distance in the Black Kite. Ecology 80: 1298-1310.

Gainzaraian, J.A., Arambarri, R. \& Rodríguez, A.F. 2000. Breeding density, habitat selection and reproductive rates of the Peregrine Falcon Falco peregrinus in Álava (northern Spain). Bird Study 47: 225-231.

Gutiérrez, R.J., Cody, M., Courtney, S. \& Franklin, A.B. 2007. The invasion of barred owls and its potential effect on the spotted owl: a conservation conundrum. Biological Invasions 9: 181-196.

Hakkarainen, H. \& Korpimäki, E. 1996. Competitive and predatory interactions among raptors: an observational and experimental study. Ecology 77: 1134-1142.

Hakkarainen, H., Ilmonen, P., Koivunen, V. \& Korpimäki, E. 2001. Experimental increase of predation risk induces breeding dispersal of Tengmalm's owl. Oecologia 126: 355259.

Hakkarainen, H., Mykrä, S., Kurki, S., Tornberg, R. \& Jungell, S. 2004. Competitive interactions among raptors in boreal forests. Oecologia 141: 420-424.

Harrison, D.J., Bisonette, J.A. \& Sherburne, J.A. 1989. Spatial relationships between coyotes and red foxes in eastern Maine. J. Wildl. Manage. 53: 181-185.

Herrera, C.M. \& Hiraldo, F. 1976. Food-niche and trophic relationships among European owls. Ornis Scand. 7: 29-41.

Holt, R.D. \& Polis, G.A. 1997. A theoretical framework for intraguild predation. Am. Nat. 149: 745-764.

Jaksic, F.M. 1982. Inadequacy of activity time as a niche difference: the case of diurnal and nocturnal raptors. Oecologia 32: 171175.

Jaksic, F.M. \& Braker, H.E. 1983. Food-niche relationships and guild structure of diurnal birds of prey: competition versus opportunism. Can. J. Zool. 61: 2230-2241.

Kelly, E.G., Forsman, E.D. \& Anthony, R.G. 2003. Are Barred Owls displacing Spotted Owls? Condor 105: 45-53.

König, C. 1999. Owls: A Guide to the Owls of the World. New Haven: Yale University Press.

Korpimäki, E. 1985. Selection for nest-hole shift and tactics of breeding dispersal in Tengmalm's owl Aegolius funereus. J. Anim. Ecol. 56: 185-196.

Korpimäki, E. \& Norrdahl, K. 1989. Avian predation on mustelids in Europe 1: occurrence and effects on body size variation and life traits. Oikos 55: 205-215.

Kostrzewa, A. 1991. Interspecific interference competition in three European raptor species. Ethol. Ecol. Evol. 3: 127143.

Krüger, O. 2002. Interactions between common buzzard Buteo buteo and goshawk Accipiter gentilis: trade-offs revealed by a field experiment. Oikos 96: 441-452.

Lima, S.L. 1998. Nonlethal effects in the ecology of predatorprey interactions - What are the ecological effects of antipredator decision-making? Bioscience 48: 25-34. 
Lima, S.L. \& Dill, L.M. 1990. Behavioral decisions made under the risk of predation: a review and prospectus. Can. J. Zool. 68: 619-640.

Luttich, S.N., Keith, L.B. \& Stephenson, J.D. 1971. Population dynamics of the Red-tailed Hawk (Buteo jamaicensis) at Rochester, Alberta. Auk 88: 75-87.

MacFadzen, M.E. \& Marzluff, J.M. 1996. Mortality of Prairie Falcons during the fledging dependence period. Condor $\mathbf{9 8}$ : 791-800.

Matsumura, M., Trafelet-Smith, G.M., Gratton, C., Finke, D.L., Fagan, W.F. \& Denno, R.F. 2004. Does intraguild predation enhance predator performance? A stoichiometric perspective. Ecology 85: 2601-2615.

McInvaille, W.B. \& Keith, L.B. 1974. Predator-prey relations and breeding biology of the Great Horned Owl and Red-tailed Hawk. Can. Field Nat. 88: 1-20.

Mikkola, H. 1976. Owls killing and killed by other owls and raptors in Europe. Br. Birds 69: 144-154.

Mikkola, H. 1983. Owls of Europe. Calton: T \& AD Poyser.

Müller, C.B. \& Brodeur, J. 2002. Intraguild predation in biological control and conservation biology. Biol. Conserv. 25: 216-223.

Mylius, S.D., Klumpers, K., de Roos, A.M. \& Persson, M. 2001. Impact of intraguild predation and stage structure on simple communities along a productivity gradient. Am. Nat. 158: 259-276.

Newton, I. 1979. Population Ecology of Raptors. Berkhamsted: $T \& A D$ Poyser.

Olson, G.S., Glenn, E.M., Anthony, R.G., Forsman, E.D., Reid, J.A., Loschl, P.J. \& Ripple, W.J. 2004. Modeling demographic performance of northern spotted owls relative to forest habitat in Oregon. J. Wildl. Manage. 68: 1039-1053.

Olson, G.S., Anthony, R.G., Forsman, E.D., Ackers, S.H., Loschl, P.J., Reid, J.A., Dugger, K.M., Glenn, E.M. \& Ripple, W.J. 2005. Modeling of site occupancy for northern spotted owls, with emphasis on the effects of barred owls. J. Wildl. Manage. 69: 918-932.

Orians, G. \& Kuhlman, F. 1956. Red-tailed Hawk and Horned Owl populations in Wisconsin. Condor 58: 371-385.

Palomares, F. \& Caro, T.M. 1999. Interspecific killing among mammalian carnivores. Am. Nat. 153: 492-508.

Palomares, F., Gaona, P., Ferreras, P. \& Delibes, M. 1995. Positive effects on game species of top predators by controlling smaller predator populations: an example with lynx, mongooses, and rabbits. Conserv. Biol. 9: 295-305.

Peacor, S.D. \& Werner, E.E. 2004. Context dependence of nonlethal effects of a predator on prey growth. Israel J. Zool. 50: 139-167.

Pearson, R.R. \& Livezey, K.B. 2003. Distribution, numbers and site characteristics of Spotted Owls and Barred Owls in the Cascade Mountains of Washington. J. Raptor Res. 37: 265276.

Petty, S. J., Anderson, D.I.K., Davison, M., Little, B., Sherratt, T.N., Thomas, C.J. \& Lambin, X. 2003. The decline of Common Kestrels Falco tinnunculus in a forested area of northern England: the role of predation by Northern Goshawks Accipiter gentilis. Ibis 145: 472-483.

Polis, G.A. \& Holt, R.D. 1992. Intraguild predation: the dynamics of complex trophic interactions. Trends Ecol. Evol. 7: 151-154.

Polis, G.A., Myers, C.A. \& Holt, R.D. 1989. The ecology and evolution of intraguild predation: potential competitors that eat each other. Ann. Rev. Ecol. Syst. 20: 297-330.

Preisser, E.L., Bolnick, D.I. \& Benard, M.F. 2005. Scared to death? The effects of intimidation and consumption in predatorprey interactions. Ecology 86: 501-509.

Radler, K. \& Bergerhausen, W. 1988. On the life history of a reintroduced population of Eagle Owls (Bubo bubo). In Garcelon, D.K. \& Roemer, G.W. (eds) Proceedings of the International Symposium on Raptor Reintroduction, 1985: 83-94. Arcata: Institute of Wildlife studies.

Ray, J.C., Redford, K.H., Steneck, R.S. \& Berger, J. (eds) 2005. Large Carnivores and the Conservation of Biodiversity. Washington: Island Press.

Reynolds, R.T., Meslow, E.C. \& Wight, H.M. 1982. Nesting habitat of coexisting Accipiter in Oregon. J. Wildl. Manage. 46: 124-138.

Roemer, G.W., Donlan, C.J. \& Courchamp, F. 2002. Golden eagles, feral pigs, and insular carnivores: How exotic species turn native predators into prey. Proc. Natl Acad. Sci. USA 99: 791-796.

Rogers, C.M. \& Caro, M.J. 1998. Song sparrows, top carnivores, and nest predation: a test of the mesopredator release hypothesis. Oecologia 116: 227-33.

Rohner, C. \& Doyle, F.I. 1992. Food-stressed Great Horned Owl kills adult Goshawk: exceptional observation or community process? J. Raptor Res. 26: 261-263.

Rohner, C. \& Hunter, D.B. 1996. First-year survival of great horned owls during a peak and decline of the snowshoe hare cycle. Can. J. Zool. 74: 1092-1097.

Rudolph, S.G. 1978. Predation ecology of coexisting Great Horned and Barn Owls. Wilson Bull. 90: 134-137.

Scheepers, J.L. \& Venzke, K.A.E. 1995. Attempts to reintroduce African wild dogs Lycaon pictus into Etosha National Park, Namibia. S. Afr. J. Wildlife Res. 25: 138-140.

Schoener, T.W. 1983. Field experiments on interspecific competition. Am. Nat. 122: 240-285.

Sergio, F. \& Newton, I. 2003. Occupancy as a measure of territory quality. J. Anim. Ecol. 72: 857-865.

Sergio, F., Marchesi, L. \& Pedrini, P. 2003a. Spatial refugia and the coexistence of a diurnal raptor with its intraguild owl predator. J. Anim. Ecol. 72: 232-245.

Sergio, F., Pedrini, P. \& Marchesi, L. 2003b. Spatio-temporal shifts in gradients of habitat quality for an opportunist avian predator. Ecography 26: 243-255.

Sergio, F., Rizzolli, F., Marchesi, L. \& Pedrini, P. 2004. The importance of interspecific interactions for breeding-site selection: peregrine falcons seek proximity to raven nests. Ecography 27: 818-826.

Sergio, F., Blas, J., Forero, M., Fernández, N., Donázar, J.A. \& Hiraldo, F. 2005a. Preservation of wide-ranging top predators by site-protection: black and red kites in Doñana National Park. Biol. Conserv. 125: 11-21.

Sergio, F., Newton, I. \& Marchesi, L. 2005b. Top predators and biodiversity. Nature 236: 192.

Sergio, F., Scandolara, C., Marchesi, L., Pedrini, P. \& Penteriani, V. 2005c. Effect of agro-forestry and landscape changes on common buzzards (Buteo buteo) in the Alps: implications for conservation. Anim. Conserv. 7: 17-25.

Sergio, F., Newton, I., Marchesi, L. \& Pedrini, P. 2006. Ecologically justified charisma: preservation of top predators delivers biodiversity conservation. J. Appl. Ecol. 43: 1049-1055.

Sergio, F., Marchesi, L., Pedrini, P. \& Penteriani, V. 2007. Coexistence of a generalist owl with its intraguild predator: distance-sensitive or habitat-mediated avoidance? Anim. Behav. 74: 1607-1616. 
Serrano, D. 2000. Relationship between raptors and rabbits in the diet of Eagle Owls in southwestern Europe: competition removal or food stress? J. Raptor Res. 34: 305-310.

Sih, A., Crowley, P., McPeek, M., Petranka, J. \& Strohmeier, K. 1985. Predation, competition, and prey communities: a review of field experiments. Ann. Rev. Ecol. Syst. 16: 269-311.

Sonerud, G.A. 1985. Risk of nest predation in three species of hole nesting owls: influence on choice of nesting habitat and incubation behaviour. Ornis Scand. 16: 261-269.

Suhonen, J., Halonen, M., Mappes, T. \& Korpimäki, E. 2007. Interspecific competition limits larders of Pygmy Owls Glaucidium passerinum. J. Avian Biol. 38: 630-634.

Sunde, P. 2005. Predators control post-fledging mortality in tawny owls, Strix aluco. Oikos 110: 461-472.

Sunde, P., Overskaug, K. \& Kvam, T. 1999. Intraguild predation of lynxes on foxes: evidence of interference competition? Ecography 22: 521-523.

Sunde, P., Bolstad, M.S. \& Desfor, K.B. 2003. Diurnal exposure as a risk sensitive behaviour in Tawny Owls Strix aluco? J. Avian Biol. 34: 409-418.

Tella, J.L. \& Mañosa, S. 1993. Eagle Owl predation on Egyptian Vulture and Northern Goshawk: possible effect of a decrease in European Rabbit availability. J. Raptor Res. 27: 111-112.

Tella, J.L., Carrete, M., Sánchez-Zapata, J.A., Serrano, D., Gavrilov, A., Skylarenko, S., Ceballos, O., Donázar, J.A. \&
Hiraldo, F. 2004. Effects of land-use, nesting-site availability, and the presence of larger raptors on the abundance of vulnerable lesser kestrels Falco naumanni in Kazakhstan. Oryx 38: 224-227.

Todd, L.D., Poulin, R.G., Wellicome, T.I. \& Brigham, R.M. 2003. Post-fledging survival of burrowing owls in Saskatchewan. J. Wildl. Manage. 67: 512-519.

Tomé, R., Bloise, C. \& Korpimäki, E. 2004. Nest-site selection and nesting success of Little Owls (Athene noctua) in Mediterranean woodland and open habitats. J. Raptor Res. 38: 35-46.

Uttendörfer, O. 1952. Neue Ergebnisse über die Ernährung der Greifvögel und Eulen. Stuttgart: Verlag Eugen Ulmer.

Voous, K.H. 1988. Owls of the Northern Hemisphere. London: Collins.

Werner, E.E. \& Peacor, S.D. 2003. A review of trait-mediated indirect interactions in ecological communities. Ecology 84: 1083-1100.

Zuberogoitia, I., Martínez, J.E., Zabala, J., Martínez, J.A., Azkona, A., Castillo, I. \& Hidalgo, S. 2007. Social interactions between two owl species sometimes associated with intraguild predation. Ardea 96: 109-113.

Received 3 August 2007; revision accepted 15 October 2007. 